\title{
Literatur Review
}

\section{Gaya Kepemimpinan Dalam Meningkatkan Keterikatan dan Kinerja Perawat}

\author{
Hanum Maftukha Ahda', Nur Hidayah' ${ }^{1}$
}

1 Program Studi Magister Administrasi Rumah Sakit Universitas Muhammadiyah Yogyakarta, Indonesia

\begin{tabular}{|c|c|}
\hline Article Info & Abstrak \\
\hline $\begin{array}{l}\text { Article History: } \\
\text { Submit: } 14 \text { Oktober } 2021 \\
\text { Accepted: } 29 \text { November } \\
2021 \\
\text { Publish: } 30 \text { November } 2021 \\
\text { Key words: } \\
\text { Nurse; Leadership; } \\
\text { Engagement; Performance }\end{array}$ & $\begin{array}{l}\text { Keterikatan dan kinerja perawat merupakan komponen penting dalam } \\
\text { mencapai tujuan Rumah Sakit. Pelayanan keperawatan berperan penting } \\
\text { dalam mencapai tujuan Rumah Sakit sehingga kepemimpinan seorang } \\
\text { perawat menjadi kunci dalam keberhasilan pelayanan tersebut. Studi ini } \\
\text { bertujuan untuk mengidentifikasi dan mensintesis penelitian tentang } \\
\text { pengaruh gaya kepemimpinan terhadap keterikatan kerja dan kinerja } \\
\text { perawat di Rumah Sakit. Penelitian ini merupakan Literature review dengan } \\
\text { penelusuran artikel melalui database elektronik Pubmed, Emerald dan } \\
\text { Sciencedirect yang diterbitkan dari tahun 2011-2021 dan memenuhi } \\
\text { kriteria inklusi. Proses review menggunakan panduan Preferred Reporting } \\
\text { Items for Systematic Reviews and Meta-Analyses (PRISMA). Sepuluh artikel } \\
\text { menunjukkan kepemimpinan memiliki pengaruh positif terhadap } \\
\text { keterikatan kerja. Lima artikel menunjukkan kepemimpinan memiliki } \\
\text { pengaruh posisitif terhadap kinerja perawat di Rumah Sakit. Kepemimpinan } \\
\text { menjadi faktor penting yang berpengaruh terhadap keterikatan kerja dan } \\
\text { kinerja perawat. Selain itu, dipengaruhi juga oleh faktor lain dari } \\
\text { sumberdaya pekerjaan dan individu. Kepemimpinan memiliki peran penting } \\
\text { dalam meningkatkan keterikatan kerja dan kinerja perawat di Rumah Sakit } \\
\text { sehingga dapat mencapai tujuan dan kinerja organisasi yang baik. }\end{array}$ \\
\hline
\end{tabular}

\section{PENDAHULUAN}

Rumah Sakit merupakan organisasi yang memiliki peran penting dalam penyelenggaraan pelayanan kesehatan (Talasaz et al., 2014). Salah satu yang memiliki peran penting dalam pelayanan kesehatan di Rumah Sakit yaitu pelayanan keperawatan. Pelayanan keperawatan merupakan bentuk pelayanan profesional yang menjadi bagian integral dari pelayanan kesehatan yang harus didasari dengan ilmu dan kemampuan(Permenkes,
2019). Organisasi pelayanan kesehatan semakin bergantung pada profesi keperawatan untuk memberikan kepemimpinan yang efektif dalam berbagai pengaturan pelayanan kesehatan yang dinamis dan kompleks (Cummings et al., 2018). Kepemimpinan merupakan proses dua arah, dua pihak yaitu satu pihak harus mengetahui cara memimpin dan pihak lain mengikuti. Dari proses dua arah ini pemimpin menunjukkan suatu perilaku yang mengarahkan dan mengkoordinasikan aktifitas dari yang dipimpin untuk 
mencapai suatu tujuan. Pemimpin merupakan agen perubahan, bertindak mempengaruhi orang lain lebih dari orang lain mempengaruhi dirinya (Gibson et al., 2009; Sfantou et al., 2017).

Pemimpin dapat meningkatkan kinerja suatu organisasi dengan mempengaruhi faktor-faktor kinerja. Salah satu bentuk pengaruhnya yaitu penggunaan perilaku kepemimpinan tertentu dalam interaksi dengan bawahan, rekan kerja, dan pihak luar (Yukl, 2008). Tipe kepemimpinan yang berbeda dapat mempengaruhi keefektifan ataupun kinerja organisasi (Nanjundeswaraswamy \& Swamy, 2012). Terdapat beberapa gaya kepemimpinan, beberapa hal yang umum yaitu transformasional, transaksional, autokratik, laissez-faire, task-oriented, dan relationship-oriented. Berbagai gaya kepemimpinan tersebut diterapkan dalam rangka mencapai tujuan organisasi (Sfantou et al., 2017). Kepemimpinan seorang perawat memiliki pengaruh terhadap kinerja perawat ('Aini \& Sosilo, 2014; Habib et al., 2020; Lai et al., 2020; Phinari \& Bernarto, 2020).

Selain gaya kepemimpinan, keterikatan kerja merupakan salah satu elemen yang mendukung dan dapat meningkatkan kinerja organisasi (Kim et al., 2013). Keterikatan kerja merupakan kegiatan penuh semangat kerja yang memiliki karakteristik semangat, dedikasi dan absorbsi. Semangat mengacu pada kesukarelaan untuk berusaha melakukan pekerjaan. Dedikasi merujuk pada keterlibatan penuh dalam bekerja, absobsi berhubungan dengan memiliki konsentrasi penuh dan tenggelam dalam pekerjaannya (W. B. Schaufeli et al., 2002). Ketika seseorang terikat dengan pekerjaannya ia akan meningkatkan kinerja dengan efisien dan efektif dalam mencapai tujuan organisasi. Hal ini menunjukkan sebuah organisasi membutuhkan karyawan yang terikat yaitu semangat, berdedikasi dan absorbs dalam pekerjaannya. Untuk itu keterikatan kerja perlu perhatian lebih untuk dipelajari serta keterikatan memiliki hubungan erat dengan kinerja dalam organisasi (Bakker \& Demerouti, 2008). Beberapa penelitian yang membahas pengaruh kepemimpinan dengan keterikatan kerja menunjukkan hasil yang positif (Babcock-Roberson \& Strickland, 2010; García-Sierra et al., 2016; Hartog \& Belschak, 2012; Xu \& Thomas, 2011).

Dalam pelayanan di Rumah Sakit, perawat memiliki peranan penting yang dapat mempengaruhi kinerja Rumah Sakit. Beberapa penelitian sudah membahas tentang hubungan kepemimpinan dengan keterikatan kerja ataupun kinerja. Untuk itu peneliti melakukan literature review ini untuk mengetahui berbagai kepemimpinan yang memiliki pengaruh positif sehingga dapat meningkatkan keterikatan kerja dan kinerja perawat terutama di Rumah Sakit. Untuk itu tujuan dari penelitian ini mengidentifikasi dan mensintesis penelitian tentang pengaruh gaya kepemimpinan dalam meningkatkan keterikatan kerja dan kinerja pada perawat di Rumah Sakit.

\section{METODE}

\section{Strategi Pencarian Literatur}

Peneliti melakukan penelusuran artikel tentang gaya kepemimpinan terhadap keterikatan kerja dan kinerja perawat melalui database elektronik yaitu PubMed, Emerald dan Sciencedirect. Penelusuran artikel menggunakan kombinasi kata kunci "Nurse", "Leadership", "Work Engagament" dan "Performance". Kriteria inklusi artikel yang dimasukkan yaitu artikel membahas kepemimpinan perawat terhadap keterikatan ataupun kinerja perawat, berbahasa inggris, diterbitkan 10 tahun terakhir (2011-2021), responden merupakan perawat di Rumah Sakit, dan menggunakan desain kuantitatif. Artikel systematic review ataupun review dan tidak tersedia akses lengkap tidak dimasukkan dalam review ini. 


\section{Mekanisme seleksi artikel}

Penyeleksian artikel menggunakan panduan protokol Preferred Reporting Items for Systematic Reviews and Meta-Analyses (PRISMA) (Page et al., 2021). Setelah dilakukan pencarian artikel melalui database didapatkan 2150 artikel. Peneliti melakukan seleksi melalui judul dan abstrak dan didapatkan 18 artikel yang dilakukan kaji secara keseluruhan. Dari proses ini didapatkan 13 artikel yang dimasukkan dalam review.

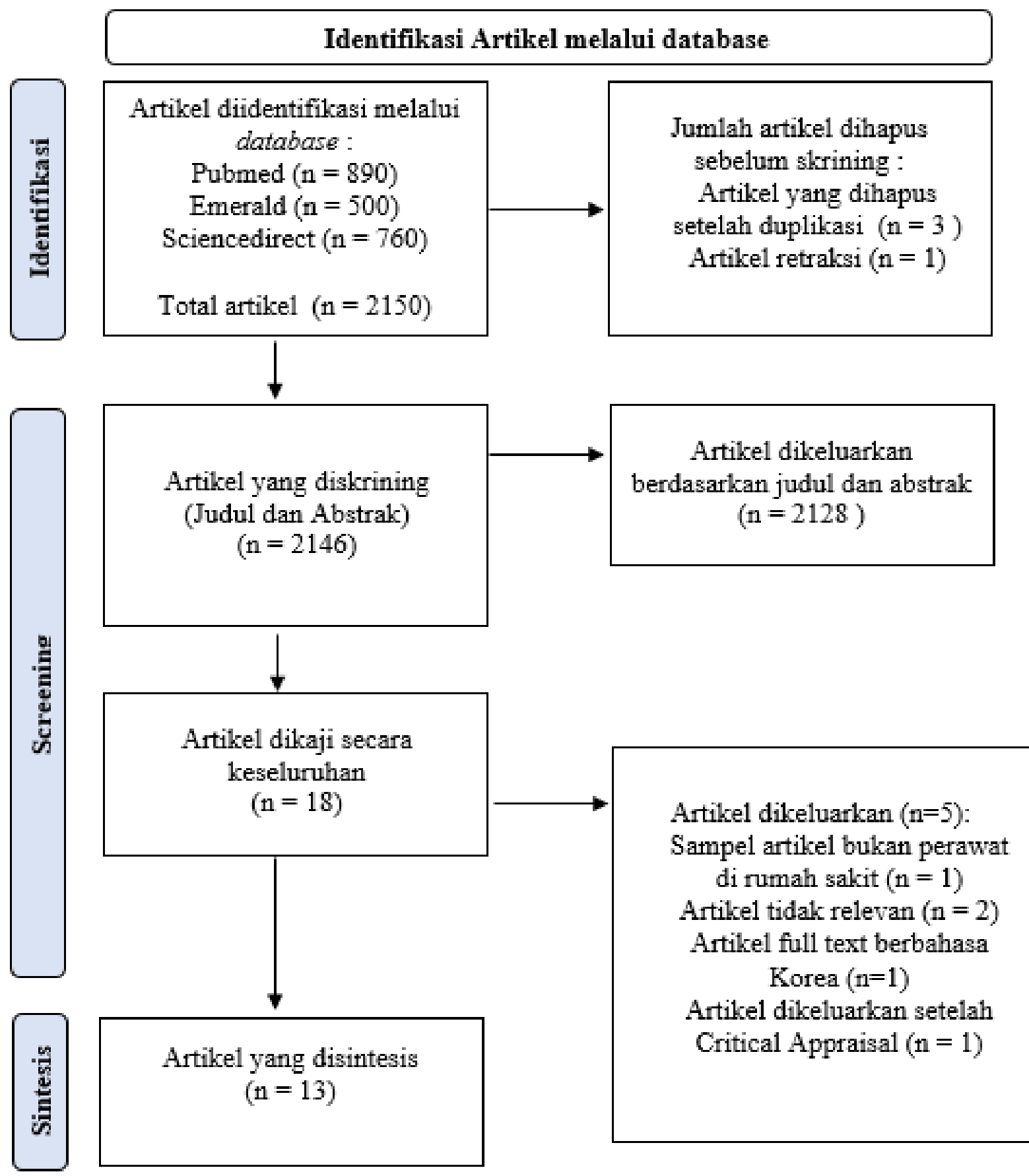

Gambar 1.

Diagram/Skema PRISMA 


\section{Ekstraksi Data}

Setelah proses seleksi artikel, artikel yang didapat dilakukan sintesis dengan format: peneliti, tahun, jurnal publikasi, lokasi, tujuan penelitian, desain penelitian, sampel, dan hasil. Hasil sintesis artikel ditampilkan pada tabel 1.

\section{HASIL}

\section{Karakteristik Artikel}

Berdasarkan hasil penelusuran artikel, didapatkan 13 artikel yang memenuhi kriteria inklusi. Seluruh artikel merupakan penelitian kuantitatif dengan pendekatan cross sectional dipublikasi antara tahun 2011-2021. Data studi yang diperoleh merupakan studi yang dilakukan pada berbagai Negara. Ada 2 studi yang dilakukan di Taiwan, dan artikel lainnya masing-masing 1 studi dari Arab Saudi, Kanada, Nigeria, Iran, India, Amerika Serikat, Irlandia, Portugis, Kanada, , China dan Korea Selatan. Penelitian dari artikel yang ditelaah, 8 artikel dilakukan multicenter dan 5 artikel hanya berfokus pada 1 Rumah Sakit. Dari 13 artikel yang ditelaah ini, 9 artikel berfokus pada perawat secara umum sedangkan 4 artikel melibatkan staf perawat dan supervisornya. Rincian dari artikel yang ditelaah disajikan pada tabel 1.

Tabel 1

Hasil review tentang kepemimpinan terhadap keterikatan kerja dan kinerja perawat

\begin{tabular}{|c|c|c|c|c|c|}
\hline No & Peneliti/Tahun/Jurnal & Tujuan Penelitian & $\begin{array}{l}\text { Desain } \\
\text { penelitian/ } \\
\text { Sampel }\end{array}$ & $\begin{array}{c}\text { Analisis } \\
\text { data }\end{array}$ & Hasil \\
\hline 1. & $\begin{array}{lr}\text { Alotaibi, } & 2020 / \\
\text { Leadership } & \& \\
\text { Organization } & \\
\text { Development } & \\
\text { Arab Saudi } & \end{array}$ & $\begin{array}{l}\text { Untuk mengetahui } \\
\text { peran intelegensi } \\
\text { emosional dan } \\
\text { kepemimpinan } \\
\text { pemberdayaan dalam } \\
\text { meningkatkan } \\
\text { pemberdayaan } \\
\text { psikologis dan } \\
\text { keterikatan kerja di } \\
\text { rumah sakit swasta }\end{array}$ & $\begin{array}{l}\text { Cross } \\
\text { sectional/ } \\
174 \quad \text { staf } \\
\text { perawat di } \\
\text { lima rumah } \\
\text { sakit swasta }\end{array}$ & PLS-SEM & $\begin{array}{l}\text { Terdapat hubungan signifikan } \\
\text { antara kecerdasan emosional, } \\
\text { kepemimpinan } \\
\text { pemberdayaan, } \\
\text { pemberdayaan psikologis dan } \\
\text { keterikatan kerja. } \\
\text { Hubungan antara kecerdasan } \\
\text { emosional dan keterikatan } \\
\text { kerja serta pemberdayaan } \\
\text { psikologis dan keterikatan } \\
\text { kerja tidak signifikan. }\end{array}$ \\
\hline 2. & $\begin{array}{l}\text { Bamford et al., } 2013 \\
\text { Journal of Nursing } \\
\text { Management/ Kanada }\end{array}$ & $\begin{array}{l}\text { Untuk } \\
\text { hubungan } \\
\text { persepsi antara } \\
\text { terhadap } \\
\text { kepemimpinan otentik } \\
\text { perawat manajer, serta } \\
\text { kesesuian individu- } \\
\text { pekerjaan dalam enam } \\
\text { aspek kehidupan kerja } \\
\text { dan keterikatan kerja }\end{array}$ & $\begin{array}{l}\text { Cross } \\
\text { sectional/ } \\
280 \text { perawat } \\
\text { di rumah } \\
\text { sakit }\end{array}$ & $\begin{array}{l}\text { Regresi } \\
\text { Berganda; } \\
\text { Analisis } \\
\text { Mediasi }\end{array}$ & $\begin{array}{l}\text { Kesesuaian } \\
\text { pekerjaan secara keseluruhan } \\
\text { dalam enam aspek kehidupan } \\
\text { kerja sepenuhnya dimediasi } \\
\text { oleh hubungan antara } \\
\text { kepemimpinan otentik dan } \\
\text { keterikatan kerja. }\end{array}$ \\
\hline 3. & $\begin{array}{l}\text { Enwereuzor dkk., } \\
2018 \\
\text { Western Journal of } \\
\text { Nursing Research/ } \\
\text { Nigeria }\end{array}$ & $\begin{array}{l}\text { Untuk menambah } \\
\text { literatur yang ada } \\
\text { tentang kepemimpinan } \\
\text { transformasional dan } \\
\text { keterikatan kerja } \\
\text { dengan } \\
\text { mempertimbangkan } \\
\text { peran moderasi dari } P J \\
\text { fit. }\end{array}$ & $\begin{array}{l}\text { Cross } \\
\text { sectional/ } \\
224 \text { staf } \\
\text { perawat } \\
\text { dari empat } \\
\text { rumah sakit } \\
\text { di Nsukka }\end{array}$ & $\begin{array}{l}\text { Regresi } \\
\text { Berganda }\end{array}$ & $\begin{array}{l}\text { Gaya kepemimpinan } \\
\text { transformasional berpengaruh } \\
\text { pada keterikatan kerja } \\
\text { perawat di Rumah Sakit. } \\
\text { PJ fit memiliki hubungan } \\
\text { positif yang signifikan dengan } \\
\text { keterikatan kerja. }\end{array}$ \\
\hline
\end{tabular}




\begin{tabular}{|c|c|c|c|c|c|}
\hline No & Peneliti/Tahun/Jurnal & Tujuan Penelitian & $\begin{array}{c}\text { Desain } \\
\text { penelitian/ } \\
\text { Sampel }\end{array}$ & $\begin{array}{c}\text { Analisis } \\
\text { data }\end{array}$ & Hasil \\
\hline 4. & $\begin{array}{l}\text { Hayati dkk, } 2014 \\
\text { SpringerPlus/Iran }\end{array}$ & $\begin{array}{l}\text { Untuk menentukan } \\
\text { pengaruh } \\
\text { kepemimpinan } \\
\text { transformasional dan } \\
\text { komponennya } \\
\text { terhadap keterikatan } \\
\text { kerja pada perawat } \\
\text { rumah sakit. }\end{array}$ & $\begin{array}{l}\text { Cross } \\
\text { sectional/ } \\
240 \text { perawat } \\
\text { dari lima } \\
\text { rumah sakit }\end{array}$ & $\begin{array}{l}\text { Regresi } \\
\text { berganda }\end{array}$ & $\begin{array}{l}\text { Kepemimpinan } \\
\text { transformasional memiliki } \\
\text { pengaruh signifikan terhadap } \\
\text { keterikatan kerja. }\end{array}$ \\
\hline 5. & $\begin{array}{l}\text { Malik, } 2018 \\
\text { Personnel Review/ } \\
\text { India }\end{array}$ & $\begin{array}{l}\text { Untuk menguji } \\
\text { pengaruh } \\
\text { kepemimpinan otentik } \\
\text { terhadap kinerja } \\
\text { kontekstual perawat } \\
\text { yang bekerja di } \\
\text { perusahaan perawatan } \\
\text { kesehatan India sambil } \\
\text { mempertimbangkan } \\
\text { modal psikologis } \\
\text { sebagai mediator. }\end{array}$ & $\begin{array}{l}\text { Cross } \\
\text { sectional/ } \\
530 \text { perawat } \\
\text { dan } 146 \\
\text { perawat } \\
\text { supervisor } \\
\text { dari } 41 \\
\text { rumah sakit }\end{array}$ & $\begin{array}{l}\text { Analisis } \\
\text { jalur } \\
\text { regresi }\end{array}$ & $\begin{array}{l}\text { Kepemimpinan otentik secara } \\
\text { positif berpengaruh terhadap } \\
\text { kinerja kontekstual perawat. } \\
\text { Modal psikologis ditemukan } \\
\text { dapat memediasi hubungan } \\
\text { antara kepemimpinan otentik } \\
\text { dan kinerja kontekstual } \\
\text { Autonomi ditemukan sebagai } \\
\text { moderator antara modal } \\
\text { psikologis dan kinerja } \\
\text { kontekstual. }\end{array}$ \\
\hline 6. & $\begin{array}{l}\text { Manning,(2016) } \\
\text { The Journal of Nursing } \\
\text { Administration } \\
\text { Amerika Serikat }\end{array}$ & $\begin{array}{l}\text { Untuk mengevaluasi } \\
\text { pengaruh gaya } \\
\text { kepemimpinan } \\
\text { manajer perawat } \\
\text { terhadap keterikatan } \\
\text { kerja staf perawat. }\end{array}$ & $\begin{array}{l}\text { Descriptive, } \\
\text { Cross } \\
\text { sectional/ } \\
441 \text { staf } \\
\text { perawat } \\
\text { dari } 3 \text { (tiga) } \\
\text { rumah sakit }\end{array}$ & $\begin{array}{l}\text { Regresi } \\
\text { Berganda }\end{array}$ & $\begin{array}{l}\text { Gaya kepemimpinan } \\
\text { transaksional dan } \\
\text { transformasional manajer } \\
\text { perawat secara positif dan } \\
\text { signifikan berpengaruh } \\
\text { terhadap keterikatan kerja staf } \\
\text { perawat. } \\
\text { Gaya kepemimpinan laissez- } \\
\text { faire manajer perawat } \\
\text { berpengaruh negative dan } \\
\text { signifikan terhadap } \\
\text { keterikatan kerja staf perawat. }\end{array}$ \\
\hline 7. & $\begin{array}{l}\text { McKenna dan Jeske, } \\
2021 \\
\text { Journal of Advanced } \\
\text { Nursing/Irlandia }\end{array}$ & $\begin{array}{l}\text { Untuk menyelidiki } \\
\text { kelelahan emosional, } \\
\text { keterikatan kerja, dan } \\
\text { intensi turnover pada } \\
\text { profesi keperawatan } \\
\text { dengan } \\
\text { mengeksplorasi efek } \\
\text { anteceden } \\
\text { kepemimpinan etis dan } \\
\text { komponen pekerjaan } \\
\text { seperti otoritas } \\
\text { keputusan. }\end{array}$ & \begin{tabular}{l}
\multicolumn{3}{l}{ Cross } \\
sectional \\
89 perawat \\
di tiga \\
rumah sakit \\
kecil di \\
Irlandia
\end{tabular} & $\begin{array}{l}\text { Korelasi } \\
\text { Pearson ; } \\
\text { Model } \\
\text { Jalur }\end{array}$ & 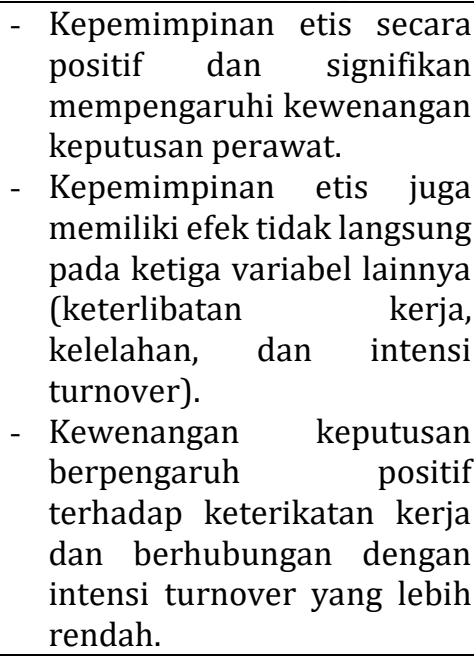 \\
\hline 8. & $\begin{array}{l}\text { Peng dan Tseng, } 2019 \\
\text { The Journal of } \\
\text { Psychology / Taiwan }\end{array}$ & $\begin{array}{l}\text { Untuk mengeksplorasi } \\
\text { efek mediasi dari } \\
\text { keterikatan kerja pada } \\
\text { hubungan antara } \\
\text { kepemimpinan } \\
\text { transformasional (TFL) } \\
\text { dan kinerja perawat, } \\
\text { bersama dengan efek } \\
\text { moderasi kesadaran }\end{array}$ & $\begin{array}{l}\text { Cross } \\
\text { sectional } \\
234 \\
\text { pasangan } \\
\text { bawahan- } \\
\text { supervisor, } \\
\text { yang terdiri } \\
\text { dari } 234 \\
\text { perawat dan }\end{array}$ & Regresi & 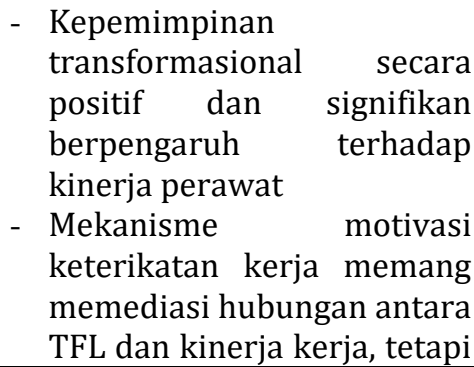 \\
\hline
\end{tabular}




\begin{tabular}{|c|c|c|c|c|c|}
\hline No & Peneliti/Tahun/Jurnal & Tujuan Penelitian & $\begin{array}{c}\text { Desain } \\
\text { penelitian/ } \\
\text { Sampel }\end{array}$ & $\begin{array}{c}\text { Analisis } \\
\text { data }\end{array}$ & Hasil \\
\hline & & $\begin{array}{l}\text { pada keterikatan kerja } \\
\text { pada hubungan } \\
\text { kepemimpinan } \\
\text { transformasional dan } \\
\text { kinerja. }\end{array}$ & $\begin{array}{l}20 \\
\text { supervisor } \\
\text { di Rumah } \\
\text { Sakit }\end{array}$ & & $\begin{array}{l}\text { hanya jika } \\
\text { conscientiousness tinggi. }\end{array}$ \\
\hline 9. & $\begin{array}{l}\text { Salanova et al., (2011) } \\
\text { Journal of Advanced } \\
\text { Nursing/ Portugis }\end{array}$ & $\begin{array}{l}\text { Untuk menguji } \\
\text { hubungan antara } \\
\text { kepemimpinan } \\
\text { transformasional } \\
\text { supervisor dan kinerja } \\
\text { staf perawat yang } \\
\text { sepenuhnya dimediasi } \\
\text { oleh efikasi diri } \\
\text { perawat dan } \\
\text { keterikatan kerja. }\end{array}$ & $\begin{array}{l}\text { Cross } \\
\text { sectional/ } \\
280 \quad \text { staf } \\
\text { perawat dan } \\
17 \\
\text { supervisor } \\
\text { di Rumah } \\
\text { Sakit } \\
79 \% \text { adalah } \\
\text { perempuan } \\
\text { dan 21\% } \\
\text { adalah laki- } \\
\text { laki }\end{array}$ & $\begin{array}{l}\text { Metode } \\
\text { SEM }\end{array}$ & 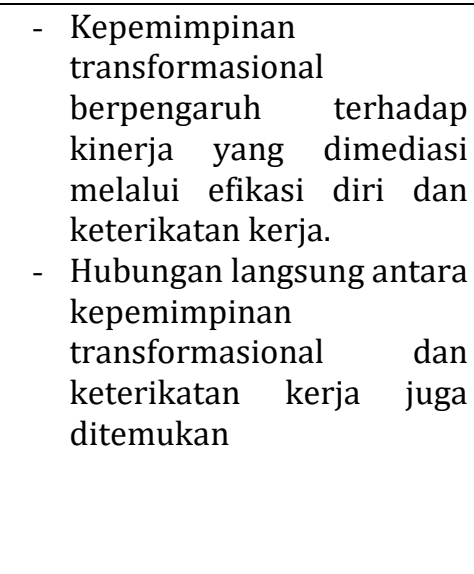 \\
\hline 10. & $\begin{array}{l}\text { Wong dan Laschinger, } \\
2013 \\
\text { Journal of Advanced } \\
\text { Nursing/Kanada }\end{array}$ & $\begin{array}{l}\text { Untuk menguji } \\
\text { hubungan } \\
\text { kepemimpinan otentik } \\
\text { manajer dengan } \\
\text { persepsi perawat } \\
\text { terhadap } \\
\text { pemberdayaan } \\
\text { struktural, kinerja, dan } \\
\text { kepuasan kerja. } \\
\end{array}$ & \begin{tabular}{l}
\multicolumn{1}{c}{ Cross } \\
sectional \\
280 \\
Perawat \\
yang \\
bekerja dari \\
$2 \quad$ rumah \\
sakit
\end{tabular} & SEM & $\begin{array}{l}\text { Kepemimpinan otentik secara } \\
\text { signifikan dan positif memiliki } \\
\text { pengaruh terhadap } \\
\text { pemberdayaan struktural staf } \\
\text { perawat, yang kemudian dapat } \\
\text { meningkatkan kepuasan kerja } \\
\text { dan kinerja. }\end{array}$ \\
\hline 11. & $\begin{array}{l}\text { Wu dan Lee, } 2020 \\
\text { International Journal } \\
\text { of Environmental } \\
\text { Research and Public } \\
\text { Health/Taiwan }\end{array}$ & $\begin{array}{l}\text { Untuk mengetahui } \\
\text { pengaruh } \\
\text { kepemimpinan } \\
\text { spiritual terhadap } \\
\text { keterikatan } r \text { kerja } \\
\text { melalui peningkatan } \\
\text { kesejahteraan spiritual } \\
\text { dan modal psikologis. }\end{array}$ & $\begin{array}{l}\text { Cross } \\
\text { sectional/ } \\
164 \text { perawat } \\
\text { di rumah } \\
\text { sakit } \\
\text { regional dan } \\
\text { pusat } \\
\text { kesehatan }\end{array}$ & $\begin{array}{l}\text { Regresi } \\
\text { linier, } \\
\text { Analisis } \\
\text { mediasi } \\
\text { sederhana }\end{array}$ & 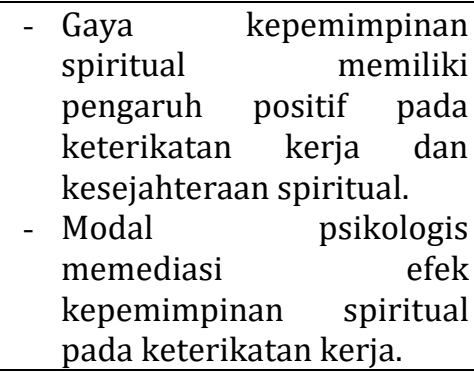 \\
\hline 12. & $\begin{array}{l}\text { Yang et al., (2019) } \\
\text { Journal of Nursing } \\
\text { Management/Cina }\end{array}$ & $\begin{array}{l}\text { Penelitian } r \text { ini } \\
\text { bertujuan untuk } \\
\text { mengetahui pengaruh } \\
\text { kepemimpinan yang } \\
\text { rendah hati terhadap } \\
\text { perilaku inovatif pada } \\
\text { perawat dan untuk } \\
\text { menguji peran mediasi } \\
\text { keterikatan kerja } \\
\text { dalam hubungan ini. }\end{array}$ & $\begin{array}{l}\text { Cross } \\
\text { sectional } \\
377 \quad \text { staf } \\
\text { perawat } \\
\text { rumah sakit }\end{array}$ & $\begin{array}{l}\text { Analisis } \\
\text { jalur }\end{array}$ & 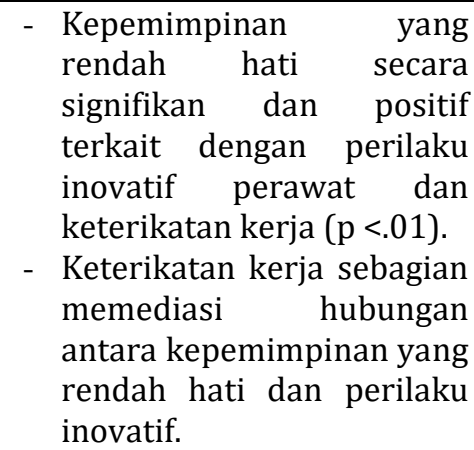 \\
\hline 13. & $\begin{array}{l}\text { Yu dan Ko , (2017) } \\
\text { Collegian/ } \quad \text { Korea } \\
\text { Selatan }\end{array}$ & $\begin{array}{l}\text { Untuk mengetahui efek } \\
\text { dari kepemimpinan } \\
\text { diri dan kompetensi } \\
\text { komunikasi terhadap } \\
\text { kinerja perawat di } \\
\text { Rumah Sakit. }\end{array}$ & $\begin{array}{l}\text { Cross } \\
\text { sectional } \\
211 \text { perawat } \\
\text { bekerja di } \\
\text { rumah sakit }\end{array}$ & $\begin{array}{l}\text { Korelasi } \\
\text { Pearson } \\
\text { Multiple } \\
\text { Regression } \\
\text { Analysis }\end{array}$ & $\begin{array}{l}\text { - Kepemimpinan diri dan } \\
\text { kompetensi komunikasi } \\
\text { memiliki hubungan positif } \\
\text { dengan kinerja perawat. } \\
\text { - Kompetensi komunikasi } \\
\text { memiliki peran sebagai } \\
\text { mediator hubungan antara } \\
\text { kepemimpinan diri dan } \\
\text { kinerja. }\end{array}$ \\
\hline
\end{tabular}




\section{Instrumen penelitian}

Seluruh artikel yang ditelaah merupakan jenis penelitian kuantitatif dengan menggunakan kuesioner. Untuk penilaian pengaruh kepemimpinan terhadap keterikatan ataupun kinerja terdapat 8 kuesioner yang berbeda yaitu Leadership Empowering Behaviour Questionnaire (Alotaibi et al., 2020), Authentic Leadership Questionnaire (Bamford et al., 2013; Malik, 2018; C. A. Wong \& Laschinger, 2013), Transformational Leadership Inventory (Enwereuzor et al., 2018), Multifactor Leadership Questionnaire (Hayati et al., 2014; Manning, 2016; Peng \& Tseng, 2019; Salanova et al., 2011), Ethical Leadership Scale (McKenna \& Jeske, 2021), Spiritual Leadership questionnaire (Wu \& Lee, 2020), Humble Leadership Scale (Yang et al., 2019), dan Self-leadership questionnaire (Yu \& Ko, 2017). Penilaian keterikatan kerja dari seluruh artikel menggunakan kuesioner Utrecht Work Engagement Scale (UWES) (W. B. Schaufeli et al., 2002, 2006; W. Schaufeli \& Bakker, 2003). Selain itu beberapa kuesioner yang juga digunakan yaitu Psychological Empowerment Questionnaire, Areas of Worklife Scale, Person-Job Fit Scale, Psychological capital scale, Contextual performance Scale, Decision Authority subscale, Emotional Exhaustion subscale from MBI, Turnover Intention scale based, International Personality Item Pool, Role-Based Job Performance Scale, Conditions of Work Effectiveness, General Performance scale, Calling questionnaire, Individual Innovative Behaviour, Nursing Job Performance dan Global Interpersonal Communication Competence. Keseluruhan instrumen yang digunakan memiliki nilai Cronbach's Alpha > 0.70 .

\section{Faktor yang mempengaruhi keterikatan}

Dari review ini didapatkan bahwa kepemimpinan memiliki pengaruh posistif terhadap keterikatan kerja. Terdapat lima artikel yang menunjukkan gaya kepemimpinan transformasional memiliki dampak terhadap keterikatan kerja pada perawat (Enwereuzor et al., 2018; Hayati et al., 2014; Manning, 2016; Peng \& Tseng, 2019; Salanova et al., 2011).

Adapun lima artikel lainnya menunjukkan, keterikatan kerja juga dipengaruhi secara signifikan oleh kepemimpinan pemberdayaan $\quad(\beta=0.548, p<0.000)$, kepemimpinan etis $(\beta=0.23, \mathrm{t}=3.09, \mathrm{p}<$ $.05)$, kepemimpinan spiritual $(\beta=0.73$, $\mathrm{p}<0.001)$, kepemimpinan transaksional $(\mathrm{P}<$ $.001)$ serta kepemimpinan otentik $(\beta=0.26$, $\mathrm{t}(267)=4.43, \mathrm{P}<0.001$ ) (Alotaibi et al., 2020; Bamford et al., 2013; Manning, 2016; McKenna \& Jeske, 2021; Wu \& Lee, 2020).

Studi yang dilakukan pada 174 staf perawat Rumah Sakit swasta di Arab menunjukkan kepemimpinan pemberdayaan memiliki dampak terhadap keterikatan kerja (Alotaibi et al., 2020). Kepemimpinan yang humble juga memiliki pengaruh yang positif terhadap keterikatan kerja $(\beta=0.41, \mathrm{p}<$ .01) (Yang et al., 2019).

Namun, pada studi yang dilakukan pada 441 staf perawat Rumah Sakit di Amerika Serikat menunjukkan bahwa gaya kepemimpinan laissez faire memiliki pengaruh negatif yang signifikan terhadap dimensi dedikasi keterikatan kerja (P $<.001)$. Tidak hanya pada dimensi dedikasi, pada dimensi absorbsi juga menunjukkan kepemimpinan laissez faire memiliki pengaruh negatif yang signifikan $(\mathrm{P}<.05)$ (Manning, 2016).

Selain itu, terdapat faktor lain seperti sumberdaya individu dan sumberdaya pekerjaan yang juga mepengaruhi keterikatan kerja. Faktor-faktor tersebut ditampilkan pada tabel 2 . 
Tabel 2

Faktor yang mempengaruhi keterikatan kerja

\begin{tabular}{|c|c|c|}
\hline Faktor yang mempengaruhi & Hasil & Sumber \\
\hline \multicolumn{3}{|l|}{ Kepemimpinan } \\
\hline - Kepemimpinan pemberdayaan & + & (Alotaibi et al., 2020) \\
\hline - Kepemimpinan Otentik & + & (Bamford et al., 2013) \\
\hline - Kepemimpinan Transformasional & + & $\begin{array}{l}\text { Enwereuzor et al., 2018; } \\
\text { Hayati et al., 2014; Manning, } \\
\text { 2016; Peng \& Tseng, 2019; }\end{array}$ \\
\hline - $\quad$ Kepemimpinan Transaksional & + & Salanova et al., 2011) \\
\hline - $\quad$ Kepemimpina Laissez-faire & - & (Manning, 2016) \\
\hline - Kepemimpinan Etis & + & (Manning, 2016) \\
\hline - $\quad$ Kepemimpinan Spiritual & + & (McKenna \& Jeske, 2021) \\
\hline - $\quad$ Kepemimpinan rendah hati & + & $\begin{array}{l}\text { (Wu \& Lee, 2020) } \\
\text { (Yang et al., 2019) }\end{array}$ \\
\hline \multicolumn{3}{|l|}{ Sumber daya individu } \\
\hline - $\quad$ Efikasi diri & + & (Salanova et al., 2011) \\
\hline - $\quad$ Modal Psikologis & + & (Wu \& Lee, 2020) \\
\hline - Kesesuaian individu-pekerjaan & + & (Enwereuzor et al., 2018) \\
\hline \multicolumn{3}{|l|}{ Sumber daya pekerjaan } \\
\hline - Kewenangan keputusan & + & (McKenna \& Jeske, 2021) \\
\hline - $\quad$ Area kehidupan kerja & + & (Bamford et al., 2013) \\
\hline
\end{tabular}

$+=$ berpengaruh positif dan signifikan

- = berpengaruh negatif dan signifikan

\section{Faktor yang mepengaruhi kinerja perawat}

Secara umum, seluruh artikel yang membahas tentang kepemimpinan dan kinerja menunjukkan bahwa kepemimpinan memiliki pengaruh positif terhadap kinerja perawat. Terdapat 5 studi yang membahas tentang kepemimpinan dan kinerja perawat dengan faktor yang mempengaruhi dari kepemimpinan tersebut berbeda-beda.

Kepemimpinan otentik berpengaruh positif terhadap kinerja kontekstual $(\beta=0.4379$, $\mathrm{t}=11.1927, \mathrm{p}<0.0000$ ). Hal ini menunjukkan pentingnya kepemimpinan otentik pada perawat (Malik, 2018). Studi yang dilakukan oleh Wong and Laschinger, (2013) juga menunjukkan kepemimpinan otentik memiliki pengaruh langsung yang positif terhadap pemberdayaan $(\beta=0 \cdot 46$, $\mathrm{P}<0 \cdot 01) \quad$ yang kemudian berpengaruh secara signifikan terhadap kinerja $(\beta=0 \cdot 17$, $\mathrm{P}<0 \cdot 01$ ). Selain itu juga didapatkan bahwa kepemimpinan otentik memiliki pengaruh tidak langsung yang signifikan terhadap kinerja $(\mathrm{z}=2 \cdot 65, \mathrm{P}<0 \cdot 01)$.
Selain kepemimpinan otentik, penelitian yang dilakukan Peng and Tseng, (2019) menunjukkan kepemimpinan transformasional memiliki pengaruh signifikan terhadap kinerja pada perawat $(\beta$ $=.47, \mathrm{p}<.01)$. Hal ini juga sejalan dengan penelitian yang dilakukan Salanova et al., (2011) bahwa kepemimpinan transformasional memiliki pengaruh terhadap kinerja bawahannya.

Kinerja perawat berhubungan dengan keefektifan kinerja Rumah Sakit. Sebuah studi yang melibatkan 211 perawat yang bekerja pada berbagai departemen di Rumah sakit menunjukkan kepemimpinan diri pemimpin juga secara signifikan memiliki dampak terhadap kinerja bawahannya $(\beta=0.410 ; p<0.001)$.

Berbagai kepeimpinan tersebut menjadi faktor yang dapat meningkatkan kinerja perawat. Selain itu, beberapa kepemimpinan dimediasi oleh faktor lainnya dalam mempengaruhi kinerja perawat. Faktor-faktor tersebut disajikan pada Tabel 3. 
Tabel 3

Faktor yang mempengaruhi kinerja perawat

\begin{tabular}{|c|c|c|}
\hline Faktor yang mempengaruhi & Hasil & Sumber \\
\hline \multicolumn{3}{|l|}{ Kepemimpinan } \\
\hline - Kepemimpinan Transformasional & + & (Peng \& Tseng, 2019; Salanova et al., 2011) \\
\hline - $\quad$ Kepemimpinan Otentik & + & (Malik, 2018; C. A. Wong \& Laschinger, 2013) \\
\hline - $\quad$ Kepemimpinan Diri & + & (Yu \& Ko, 2017) \\
\hline Keterikatan kerja & + & (Peng \& Tseng, 2019; Salanova et al., 2011) \\
\hline \multicolumn{3}{|l|}{ Sumber daya pekerjaan } \\
\hline - Otonomi & + & (Malik, 2018) \\
\hline \multicolumn{3}{|l|}{ Sumber daya individu } \\
\hline - Conscientiousness & + & (Peng \& Tseng, 2019) \\
\hline - $\quad$ Modal psikologis & + & (Malik, 2018) \\
\hline - $\quad$ Kompetensi komunikasi & + & (Yu \& Ko, 2017) \\
\hline
\end{tabular}

$+=$ berpengaruh positif dan signifikan

\section{PEMBAHASAN}

\section{Kepemimpinan dan Pengaruh terhadap Keterikatan Kerja}

Dari review ini kepemimpinan diketahui memiliki pengaruh positif terhadap keterikatan kerja perawat. Hal ini menunjukkan dengan perilaku kepemimpinan yang digunakan dapat meningkatkan keterikatan seorang perawat terhadap pekerjaannya. Keterikatan kerja merupakan kegiatan penuh semangat kerja yang memiliki karakteristik vigor, dedikasi dan absorbsi. Vigor mengacu pada kesukarelaan untuk berusaha melakukan pekerjaan. Dedikasi merujuk pada keterlibatan penuh dalam bekerja, absobsi berhubungan dengan memiliki konsentrasi penuh dan tenggelam dalam pekerjaannya (W. B. Schaufeli et al., 2002).

Penelitian yang dilakukan oleh Alotaibi et al., (2020) menunjukkan seorang pemimpin yang memiliki tingkat kecerdasan emosi yang tinggi dapat mendukung pemberdayaan kepemimpinan sehingga meningkatkan keterikatan kerja. Seseorang yang memiliki kecerdasan emosi dapat mengetahui bagaimana emosi dirinya, emosi orang lain serta dapat mengatur emosi tersebut sehingga mendorong terciptanya aktifitas yang membangun (C.-S. Wong \& Law, 2002). Kepemimpinan pemberdayaan merupakan suatu proses perilaku seorang pemimpin untuk mempengaruhi bawahannya dengan berbagi kekuasaan dan informasi, memberikan dukungan dan kepercayaan dalam pengambilan keputusan serta kemampuan bekerja dalam batas-batas untuk mencapai tujuan organisasi (Amundsen \& Martinsen, 2014; Cheong et al., 2016). Perawat yang merasakan tingkat pemberdayaan yang tinggi akan lebih termotivasi untuk mencapai keterikatan terhadap pekerjaannya. Untuk itu penting bagi seorang manajer untuk membangun kecerdasan emosi dan pemberdayaan kepemimpinan seorang perawat sehingga dapat mendukung kerja tim perawat.

Dari review ini didapatkan kepemimpinan otentik, kepemimpinan etis, kepemimpinan spiritual, kepemimpinan yang rendah hati, serta kepemimpinan transaksional memiliki pengaruh terhadap keterikatan kerja perawat di Rumah Sakit (Bamford et al., 2013; Manning, 2016; McKenna \& Jeske, 2021; Wu \& Lee, 2020). Menurut Avolio (2004) dalam Bamford et al., (2013) kepemimpinan otentik merupakan pola perilaku seorang pemimpin yang menekankan pada integritas perilaku, konsistensi, kesadaran diri, transparansi serta kejujuran. Komponen dari kepemimpinan otentik berhubungan dengan berbagai hasil pada staf layanan kesehatan meliputi kepuasan kerja, keterikatan kerja, dan sikap yang baik (Alilyyani et al., 2018). Sedangkan, kepemimpinan etis menurut Brown and 
Treviño, (2006) merupakan gaya kepemimpinan dimana seorang pemimpin memiliki karakteristik jujur, peduli terhadap orang lain, bersikap adil, dan berperilaku sesuai norma atau etika yang berlaku. Kepemimpinan etis memiliki pengaruh tidak langsung terhadap keterikatan kerja melalui faktor pengambilan keputusan. Dengan kepemimpinan etis akan berpengaruh terhadap kewenangan pengambilan keputusan yang kemudian berpengaruh positif terhadap keterikatan kerja (McKenna \& Jeske, 2021).

Selain itu, pemimpin dengan kepemimpinan spiritual mempengaruhi bawahannya melalui dampak yang positif terhadap aspek spiritual, memegang nilai altruistik dan peduli terhadap karyawannya. Pemimpin spiritual memperlakukan karyawannya dengan peduli, menghargai, dan percaya, hal ini dapat membangun lingkungan kerja yang hangat sehingga mendorong karyawan untuk terikat (Wu \& Lee, 2020). Sedangkan seorang pemimpin dengan kepemimpinan yang rendah hati mengakui kesalahan dan kekurangannya serta menghargai kekuatan dan kontribusi orang lain, sehingga menginspirasi karyawannya untuk mendapatkan evaluasi positif dari pemimpin (Wang et al., 2018). Perawat lebih mencurahkan energi dan sumberdaya pribadinya dalam bekerja dengan seorang pemimpin yang rendah hati. Hal ini juga mendorong perawat memiliki perilaku inovatif ketika terikat dengan pekerjaannya (Yang et al., 2019).

Secara umum, dari hasil review ini kepemimpinan transformasional paling banyak dilaporkan dalam mempengaruhi keterikatan kerja pada perawat. Kepemimpinan transformasional merupakan gaya kepemimpinan yang mengubah dan memotivasi pengikut untuk bekerja melebihi kepentingan pribadi dengan mengubah moral, cita-cita, minat dan nilai masing-masing untuk hasil yang terbaik bagi organisasi (Avolio et al., 2009; Pieterse et al., 2010). Kepemimpinan transformasional memiliki dampak positif dan signifikan terhadap keterikatan kerja pada perawat (Enwereuzor et al., 2018; Hayati et al., 2014; Manning, 2016; Peng \& Tseng, 2019; Salanova et al., 2011). Seorang perawat di rumah sakit yang mendapatkan dukungan, bimbingan dan terinspirasi dari supervisor cenderung merasa pekerjaannya lebih menarik, menantang dan menyegarkan sehingga merasa lebih terikat dengan pekerjaannya (Enwereuzor et al., 2018).

Pada penelitian yang dilakukan Manning (2016), keterikatan kerja juga dipengaruhi secara positif dan signifikan oleh kepemimpinan transaksional. Kepemimpinan transaksional berfokus pada pendekatan manajemen kontingesi dengan penghargaan dan manajemen pengecualian dengan memantau kinerja dan melakukan perbaikan ketika terjadi masalah (Pieterse et al., 2010; Smith, 2015). Pada saat seorang pemimpin dengan kepemimpinan transaksional melakukan manajemen penghargaan maka staf perawat akan semakin merasa terikat.

Namun, dari review ini juga didapatkan gaya kepemimpinan yang memiliki pengaruh negatif yaitu kepemimpinan laissez-faire. Kepemimpinan laissez-faire merupakan suatu kepemimpinan pasif dimana pemimpin lepas tangan membiarkan anggotanya melakukan keputusan sendiri, tidak memberikan saran serta kurang memperhatikan kekurangan dan kelebihan anggota (Avolio, 2010). Hal ini menjelaskan ketika seorang pemimpin menunda pengambilan keputusan dan tidak memberikan saran terhadap anggotanya maka berdampak negatif terhadap keterikatan kerja (Manning, 2016).

Oleh karena itu, keterikatan kerja perawat merupakan hal yang penting dalam sebuah organisasi kesehatan seperti Rumah Sakit. Perawat yang memiliki rasa keterikatan yang tinggi dengan pekerjaannya akan sukarela untuk mencurahkan tenaga dan pikirannya untuk menyelesaikan 
pekerjaannya sehingga hal ini juga berdampak pada produktifitas rumah sakit. Untuk mencapai keterikatan tersebut diperlukan peran penting dari kepemimpinan.

\section{Sumberdaya Pekerjaan}

Dari review ini didapatkan keterikan kerja dipengaruhi oleh sumberdaya pekerjaan yaitu kewenangan keputusan dan enam area kehidupan kerja, baik secara langsung ataupun tidak langsung (Bamford et al., 2013; McKenna \& Jeske, 2021). Kesesuaian individu-pekerjaan pada enam area kehidupan kerja ini memediasi hubungan kepemimpinan otentik dengan keterikatan kerja. Enam area kehidupan kerja tersebut meliputi kontrol diri/otonomi, penghargaan, beban kerja, value, keadilan dan komunitas. Semakin seorang perawat merasa pemimpinnya menunjukkan kepemimpinan otentik maka ia akan semakin merasa sesuai dengan pekerjaannya dan terikat (Bamford et al., 2013).

Sedangkan kewenangan pengambilan keputusan mengacu pada kebebasan yang dimiliki pekerja untuk memilih dan merencanakan pekerjaannya yang hal ini terkait erat dengan partisipasi dan keterlibatan. Pengaruh kewenangan pengambilan keputusan harus didukung peran dari pemimpin. Kepercayaan dan dukungan dari pemimpin dapat mendorong individu mengambil keputusan yang bertanggung jawab (McKenna \& Jeske, 2021).

\section{Sumberdaya Individu}

Dari review ini didapatkan keterikatan kerja dipengaruhi oleh sumberdaya individu yaitu modal psikologis, kesesuaian individu-pekerjaan dan efikasi diri (Enwereuzor et al., 2018; Salanova et al., 2011; Wu \& Lee, 2020). Modal psikologis merupakan kondisi perkembangan positif psikologis individu yang memiliki karakteristik efikasi diri, optimis, ketahanan dan memiliki harapan untuk mencapai kesuksesan (Luthans et al., 2015). Seorang karyawan dengan modal psikologis cenderung lebih terikat terhadap pekerjaannya. Seorang pemimpin dengan kepemimpinan spiritual dapat mendorong modal psikologis yang kemudian hal ini dapat meningkatkan keterikatan kerja staf perawat (Wu \& Lee, 2020).

Selain itu, kesesuaian individu dengan pekerjaannya menjadi faktor yang memediasi hubungan kepemimpinan transformasional dengan keterikatan kerja (Enwereuzor et al., 2018). Kesesuaian individu dengan pekerjaannya merujuk pada kemampuan seseorang pada pekerjaanya tersebut (Kristof-Brown et al., 2005). Jika seorang karyawan merasa cocok dengan pekerjaan yang dilakukan maka akan cenderung terikat dengan pekerjaannya (Bui et al., 2017). Sehingga pengaruh dari kepemimpinan transformasional terhadap keterikatan kerja perawat ini memberikan pengaruh pada perawat untuk lebih termotivasi jika pekerjaan tersebut sesuai dengan individu tersebut.

Sedangkan efikasi diri merupakan keyakinan individu terhadap kemampuannya dalam mengatur dan menghadapi situasi sehingga dapat menghasilkan tindakan yang sesuai. Semakin tinggi efikasi diri akan semakin meningkatkan keterikatan kerja (Salanova et al., 2011).

\section{Kepemimpinan dan Pengaruh terhadap Kinerja Perawat}

Kinerja merupakan suatu hasil yang dicapai seseorang dalam pekerjaannya yang hal ini berhubungan dengan kesuksesan organisasi (Cummings et al., 2018). Gaya kepemimpinan otentik, kepemimpinan transformasional dan kepemimpinan diri memiliki pengaruh yang signifikan terhadap kinerja perawat (Malik, 2018; Peng \& Tseng, 2019; Salanova et al., 2011; C. 
A. Wong \& Laschinger, 2013; Yu \& Ko, 2017).

Menurut Avolio, kepemimpinan otentik merupakan pola perilaku seorang pemimpin yang menekankan pada integritas perilaku, kesadaran diri, konsistensi, transparansi serta kejujuran (Malik, 2018). Diketahui juga kepemimpinan otentik berpengaruh positif terhadap kinerja melalui efek dari pemberdayaan struktural. Hal ini menunjukkan, semakin manajer perawat dilihat sebagai pemimpin otentik dan semakin perawat memiliki akses terhadap sumberdaya ditempat kerja maka akan semakin bekerja dengan lebih baik (C. A. Wong \& Laschinger, 2013).

\section{Kepemimpinan}

transformasional memaksimalkan potensi pengikut melalui dorongan inovasi, kreativitas, dan stimulasi intelektual. Sehingga seorang pemimpin transformasional dapat memberikan pengaruh peningkatan kinerja dari staf anggotanya (Peng \& Tseng, 2019; Salanova et al., 2011). Sedangkan, kepemimpinan diri merupakan strategi berfikir dan perilaku yang digunakan untuk mempengaruhi diri dan terlibat dalam perilaku yang bertanggung jawab ketika diberikan otonomi dan tanggung jawab. Hal ini dapat berpengaruh positif terhadap kinerja perawat (Yu \& Ko, 2017).

\section{Sumberdaya Pekerjaan}

Dari review ini didapatkan kinerja dipengaruhi oleh sumberdaya pekerjaan yaitu otonomi. Faktor otonomi disini bertindak sebagai mediator antara modal psikologis dan kinerja kontekstual pada pengaruh kepemimpinan otentik terhadap modal psikologis. Semakin tinggi otonomi perawat maka semakin baik kinerja perawat (Malik, 2018).

\section{Sumberdaya Individu}

Dari review ini didapatkan kinerja dipengaruhi oleh sumberdaya pekerjaan yaitu modal psikologis, conscientiousness, dan kompetensi komunikasi (Malik, 2018; Peng \& Tseng, 2019; Yu \& Ko, 2017). Modal psikologis merupakan kondisi perkembangan positif psikologis individu yang memiliki karakteristik efikasi diri, optimis, ketahanan dan memiliki harapan untuk mencapai kesuksesan (Luthans et al., 2015). Modal psikologis juga dipengaruhi oleh kepemimpinan otentik. Dengan kata lain, kepemimpinan otentik dapat mendorong perawat untuk meningkatkan kinerja dan mengembangkan modal psikologis mereka (Malik, 2018).

Conscientiousness merupakan suatu kepribadian yang melibatkan sifat tanggung jawab, terorganisir, teliti, bekerja keras dan berorientasi pada tujuan (Roberts et al., 2009). Conscientiousness berperan sebagai mediator hubungan kepemimpinan transformasional dan kinerja perawat. Dengan kata lain, perawat yang memiliki kepribadian conscientiousness pada konteks kepemimpinan transformasional akan meningkatkan kinerja perawat sehingga akan bekerja lebih baik (Peng \& Tseng, 2019).

Sedangkan, kompetensi komunikasi ditemukan sebagai mediator hubungan antara kepemimpinan diri dengan kinerja perawat. Kompetensi komunikasi dapat memberikan pengaruh terhadap perawat dalam memahami perannya dan memahami perilaku orang lain sehingga hal ini merupakan hal yang penting dalam pelayanan keperawatan. Sehingga dalam meningkatkan kinerja perawat dapat dilakukan dengan meningkatkan kepemimpinan diri dan kompetensi komunikasi (Yu \& Ko, 2017).

Pada review ini juga terdapat keterbatasan. Sumber artikel yang didapatkan masih sedikit dalam membahas berbagai gaya kepemimpinan tersebut. Serta pada review artikel ini seluruhnya menggunakan desain penelitian kuantitatif dengan pendekatan cross-sectional. Hal ini tidak dapat memberikan gambaran pengaruh tersebut 
dalam jangka waktu yang panjang. Namun, dari tujuan dari review artikel ini untuk mengetahui pengaruh dari kepemimpinan terhadap keterikatan kerja dan kinerja pada perawat. Dengan penelitian cross-sectional hal itu membantu menjelaskan pengaruh antara variable tersebut.

\section{SIMPULAN}

Kepemimpinan memiliki peran penting dalam meningkatkan keterikatan kerja perawat di Rumah Sakit melalui gaya kepemimpinan otentik, kepemimpinan transformasional, kepemimpinan transaksional, kepemimpinan etis, kepemimpinan spiritual, kepemimpinan pemberdayaan, dan kepemimpinan rendah hati. Sedangkan kepemimpinan yang memiliki pengaruh dalam meningkatkan kinerja perawat yaitu kepemimpinan transformasional, kepemimpinan otentik dan kepemimpinan diri. Mengetahui faktor tersebut dibutuhkan sehingga dengan keterikatan dan kinerja yang tinggi dari perawat dapat mendukung dan mencapai tujuan organisasi.

\section{Bagi Rumah Sakit dapat} mempertimbangkan untuk melakukan program pelatihan tentang kepemimpinan pada perawat dan menyediakan akses sumberdaya yang sesuai bagi staf perawat. Serta untuk penelitian lebih lanjut dapat menggunakan metode penelitian yang berbeda dan faktor gaya kepemimpinan yang lainnya sehingga dapat memahami lebih lanjut tentang faktor-faktor yang mempengaruhi keterikatan kerja ataupun kinerja perawat.

\section{UCAPAN TERIMAKASIH}

Terimakasih kepada semua pihak yang telah membantu penulis dalam penelitian ini dan kepada Program Studi Magister Administrasi Rumah Sakit Universitas Muhammadiyah Yogyakarta yang telah memberikan kesempatan dan fasilitas untuk melakukan penelitian ini.

\section{REFERENSI}

'Aini, Q., \& Sosilo, H. (2014). Pengaruh Gaya Kepemimpinan Dan Kepuasan Kerja Terhadap Kinerja Perawat Di Ruang Rawat Inap A Rsup Dr. Soeradji Tirtonegoro Klaten. JMMR (Jurnal Medicoeticolegal Dan Manajemen Rumah Sakit), 3(1), Article 1. https://journal.umy.ac.id/index.php/mrs/art icle/view/965

Alilyyani, B., Wong, C. A., \& Cummings, G. (2018). Antecedents, mediators, and outcomes of authentic leadership in healthcare: A systematic review. International Journal of Nursing Studies, 83, 34-64. https://doi.org/10.1016/j.ijnurstu.2018.04.0 01

Alotaibi, S. M., Amin, M., \& Winterton, J. (2020). Does emotional intelligence and empowering leadership affect psychological empowerment and work engagement? Leadership \& Organization Development Journal, 41(8), 971-991. https://doi.org/10.1108/LODJ-072020-0313

Amundsen, S., \& Martinsen, $\quad$. L. (2014). Empowering leadership: Construct clarification, conceptualization, and validation of a new scale. The Leadership Quarterly, 25(3), 487-511. https://doi.org/10.1016/j.leaqua.2013.11.00 9

Avolio, B. J. (2010). Full Range Leadership Development. SAGE Publications.

Avolio, B. J., Walumbwa, F. O., \& Weber, T. J. (2009). Leadership: Current theories, research, and future directions. Annual Review of Psychology, 60, 421-449. https://doi.org/10.1146/annurev.psych.60.1 10707.163621

Babcock-Roberson, M. E., \& Strickland, O. J. (2010). The Relationship Between Charismatic Leadership, Work Engagement, and Organizational Citizenship Behaviors. The Journal of Psychology, 144(3), 313-326. https://doi.org/10.1080/002239810036483 36

Bakker, A. B., \& Demerouti, E. (2008). Towards a model of work engagement. Career Development International, 13(3), 209-223. https://doi.org/10.1108/136204308108704 76

Bamford, M., Wong, C. A., \& Laschinger, H. (2013). The influence of authentic leadership and areas of worklife on work engagement of registered nurses. Journal of Nursing Management, 21(3), 529-540. 
https://doi.org/10.1111/j.1365-

2834.2012.01399.x

Brown, M. E., \& Treviño, L. K. (2006). Ethical leadership: A review and future directions. The Leadership Quarterly, 17(6), 595-616. https://doi.org/10.1016/j.leaqua.2006.10.00 4

Bui, H. T. M., Zeng, Y., \& Higgs, M. (2017). The role of person-job fit in the relationship between transformational leadership and job engagement. Journal of Managerial Psychology, 32(5), 373-386. https://doi.org/10.1108/JMP-05-2016-0144

Cheong, M., Spain, S. M., Yammarino, F. J., \& Yun, S. (2016). Two faces of empowering leadership: Enabling and burdening. The Leadership Quarterly, 27(4), 602-616. https://doi.org/10.1016/j.leaqua.2016.01.00 6

Cummings, G. G., Tate, K., Lee, S., Wong, C. A., Paananen, T., Micaroni, S. P. M., \& Chatterjee, G. E. (2018). Leadership styles and outcome patterns for the nursing workforce and work environment: A systematic review. International Journal of Nursing Studies, 85, 19-60.

https://doi.org/10.1016/j.ijnurstu.2018.04.0 16

Enwereuzor, I. K., Ugwu, L. I., \& Eze, O. A. (2018). How Transformational Leadership Influences Work Engagement Among Nurses: Does Person-Job Fit Matter? Western Journal of Nursing Research, 40(3), 346-366. https://doi.org/10.1177/019394591668244 9

García-Sierra, R., Fernández-Castro, J., \& MartínezZaragoza, F. (2016). Work engagement in nursing: An integrative review of the literature. Journal of Nursing Management, 24(2),

E101-111. https://doi.org/10.1111/jonm.12312

Gibson, J. L., Ivancevich, J. M., \& Donnelly, J. H. (2009). Organization Behavior, Structure, Processes. McGraw-Hill.

Habib, N., Awan, S. H., Naveed, S., \& Shoaib Akhtar, C. (2020). Effectiveness of Interpersonal Leadership for Engagement and Task Performance of Nurses. SAGE Open, 10(2), 2158244020924429.

https://doi.org/10.1177/215824402092442 9

Hartog, D. N., \& Belschak, F. D. (2012). Work Engagement and Machiavellianism in the Ethical Leadership Process. Journal of Business Ethics, 107(1), 35-47. https://doi.org/10.1007/s10551-012-12964
Hayati, D., Charkhabi, M., \& Naami, A. (2014). The relationship between transformational leadership and work engagement in governmental hospitals nurses: A survey study. SpringerPlus, 3, 25. https://doi.org/10.1186/2193-1801-3-25

Kim, W., Kolb, J. A., \& Kim, T. (2013). The Relationship Between Work Engagement and Performance: A Review of Empirical Literature and a Proposed Research Agenda. Human Resource Development Review, 12(3), 248-276. https://doi.org/10.1177/153448431246163 5

Kristof-Brown, A. L., Zimmerman, R. D., \& Johnson, E. C. (2005). Consequences of individual's fit at work: A meta-analysis of person-job, personorganization, person-group, and personsupervisor fit. Personnel Psychology, 58(2), 281-342. https://doi.org/10.1111/j.17446570.2005.00672.x

Lai, F.-Y., Tang, H.-C., Lu, S.-C., Lee, Y.-C., \& Lin, C.-C. (2020). Transformational Leadership and Job Performance: The Mediating Role of Work Engagement. SAGE Open, 10(1), 2158244019899085. https://doi.org/10.1177/215824401989908 5

Luthans, F., Youssef, C. M., \& Avolio, B. J. (2015). Psychological Capital and Beyond. Oxford University Press.

Malik, N. (2018). Authentic leadership - an antecedent for contextual performance of Indian nurses. Personnel Review, 47(6), 12441260. https://doi.org/10.1108/PR-07-20160168

Manning, J. (2016). The Influence of Nurse Manager Leadership Style on Staff Nurse Work Engagement. The Journal of Nursing Administration, 46(9), 438-443. https://doi.org/10.1097/NNA.00000000000 00372

McKenna, J., \& Jeske, D. (2021). Ethical leadership and decision authority effects on nurses' engagement, exhaustion, and turnover intention. Journal of Advanced Nursing, 77(1), 198-206. https://doi.org/10.1111/jan.14591

Nanjundeswaraswamy, T. S., \& Swamy, D. D. R. (2012). Quality of Work Life and Leadership Styles: An Overview. 6.

Page, M. J., McKenzie, J. E., Bossuyt, P. M., Boutron, I., Hoffmann, T. C., Mulrow, C. D., Shamseer, L., Tetzlaff, J. M., Akl, E. A., Brennan, S. E., Chou, R., Glanville, J., Grimshaw, J. M., Hróbjartsson, A., Lalu, M. M., Li, T., Loder, E. W., Mayo-Wilson, E., McDonald, S., ... Moher, D. (2021). The PRISMA 2020 statement: An updated 
guideline for reporting systematic reviews. BMJ, $\quad 372, \quad \mathrm{n} 71$. https://doi.org/10.1136/bmj.n71

Peng, J.-C., \& Tseng, M.-M. (2019). Antecedent and Consequence of Nurse Engagement. The Journal of Psychology, 153(3), 342-359. https://doi.org/10.1080/00223980.2018.15 36639

Permenkes. (2019). Peraturan Menteri Kesehatan Republik Indonesia Nomor 26 Tahun 2019 Tentang Peraturan Pelaksanaan UndangUndang Nomor 38 Tahun 2014 Tentang Keperawatan. Kementerian Kesehatan Republik Indonesia.

Phinari, H., \& Bernarto, I. (2020). THE EFFECT OF MOTIVATION, WORK ENVIRONMENT, AND TRANSFORMATIONAL LEADERSHIP ON NURSE PERFORMANCE (CASE IN S HOSPITAL). Dinasti International Journal of Management Science, 1(5), 685-694. https://doi.org/10.31933/dijms.v1i5.281

Pieterse, A. N., Knippenberg, D. van, Schippers, M., \& Stam, D. (2010). Transformational and transactional leadership and innovative behavior: The moderating role of psychological empowerment. Journal of Organizational Behavior, 31(4), 609-623. https://doi.org/10.1002/job.650

Roberts, B. W., Jackson, J. J., Fayard, J. V., Edmonds, G., \& Meints, J. (2009). Conscientiousness. In Handbook of individual differences in social behavior (pp. 369-381). The Guilford Press.

Salanova, M., Lorente, L., Chambel, M. J., \& Martínez, I. M. (2011). Linking transformational leadership to nurses' extra-role performance: The mediating role of self-efficacy and work engagement. Journal of Advanced Nursing, 67(10), 2256-2266. https://doi.org/10.1111/j.13652648.2011.05652.x

Schaufeli, W. B., Bakker, A. B., \& Salanova, M. (2006). The Measurement of Work Engagement With a Short Questionnaire: A Cross-National Study. Educational and Psychological Measurement, 66(4), 701-716. https://doi.org/10.1177/001316440528247 1

Schaufeli, W. B., Salanova, M., Lez-Roma, V. G., \& Bakker, A. B. (2002). The Measurement of Engagement And Burnout: A Two Sample Confirmatory Factor Analytic Approach. Journal of Happiness Studies, 71-92. https://doi.org/10.1023/A:1015630930326

Schaufeli, W., \& Bakker, A. (2003). Utrecht work engagement scale: Preliminary manual. Utrecht. Occupational Health Psychology Unit,Utrecht University.
Sfantou, D., Laliotis, A., Patelarou, A., Sifaki- Pistolla, D., Matalliotakis, M., \& Patelarou, E. (2017). Importance of Leadership Style towards Quality of Care Measures in Healthcare Settings: A Systematic Review. Healthcare, 5(4),

73. https://doi.org/10.3390/healthcare5040073

Smith, P. O. (2015). Leadership in Academic Health Centers: Transactional and Transformational Leadership. Journal of Clinical Psychology in Medical Settings, 22(4), 228-231. https://doi.org/10.1007/s10880-015-94418

Talasaz, Z. H., Nourani Saadoldin, S., \& Taghi Shakeri, M. (2014). The Relationship Between Job Satisfaction and Job Performance Among Midwives Working in Healthcare Centers of Mashhad, Iran. Journal of Midwifery and Reproductive Health, 2(3), 157-164. https://doi.org/10.22038/jmrh.2014.2623

Wang, L., Owens, B. P., Li, J. J., \& Shi, L. (2018). Exploring the affective impact, boundary conditions, and antecedents of leader humility. The Journal of Applied Psychology, 103(9), 1019-1038. https://doi.org/10.1037/apl0000314

Wong, C. A., \& Laschinger, H. K. S. (2013). Authentic leadership, performance, and job satisfaction: The mediating role of empowerment. Journal of Advanced Nursing, 69(4), 947-959. https://doi.org/10.1111/j.13652648.2012.06089.x

Wong, C.-S., \& Law, K. S. (2002). The effects of leader and follower emotional intelligence on performance and attitude: An exploratory study. The Leadership Quarterly, 13(3), 243274. https://doi.org/10.1016/S10489843(02)00099-1

Wu, W.-L., \& Lee, Y.-C. (2020). How Spiritual Leadership Boosts Nurses' Work Engagement: The Mediating Roles of Calling and Psychological Capital. International Journal of Environmental Research and Public Health, 17(17). https://doi.org/10.3390/ijerph17176364

Xu, J., \& Thomas, H. (2011). How can leaders achieve high employee engagement? Leadership \& Organization Development Journal, 32(4), 399-416. https://doi.org/10.1108/014377311111346 61

Yang, K., Zhou, L., Wang, Z., Lin, C., \& Luo, Z. (2019). Humble leadership and innovative behaviour among Chinese nurses: The mediating role of work engagement. Journal of Nursing Management, 27(8), 1801-1808. https://doi.org/10.1111/jonm.12879 
Jurnal Kepemimpinan dan Manajemen Keperawatan, Vol 4 No 2, November 2021

Yu, S., \& Ko, Y. (2017). Communication competency as a mediator in the self-leadership to job performance relationship. Collegian, 24(5), 421-425.

https://doi.org/10.1016/j.colegn.2016.09.00 2
Yukl, G. (2008). How leaders influence organizational effectiveness. The Leadership Quarterly, 19(6), 708-722. https://doi.org/10.1016/j.leaqua.2008.09.00 8 